\title{
Age and palaeoenvironments of the Manacapuru Formation, Presidente Figueiredo (AM) region, Lochkovian of the Amazonas Basin
}

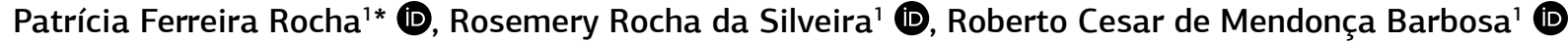

\begin{abstract}
The Manacapuru Formation, Amazonas Basin, outcrops on the margins of a highway in the region of Presidente Figueiredo, state of Amazonas. A systematic palynological and a lithofaciological analysis was carried out aiming to contribute to the paleoenvironmental understanding of the Manacapuru Formation and its respective age. The present work uses the analysis of the chitinozoan for biostratigraphic purposes as a tool. A total of 27 samples were collected in which an assemblage of lower Lochkovian can be recognized, whose characteristic species are Angochitina filosa, Cingulochitina ervensis, Lagenochitina navicula, and Pterochitina megavelata. It was possible to identify an intense reworking in the exposure, evidenced by the presence of paleofaunas ranging from Ludfordian to Pridolian, which may be associated to the constant storm events that reached the shelf. The lithofaciological analysis allowed the recognition of 6 predominantly muddy sedimentary lithofacies with sandy intercalations that suggest deposition in an offshore region inserted in a shallow marine shelf and influenced by storms.
\end{abstract}

KEYWORDS: Chitinozoan; Devonian; Manacapuru Formation; Amazonas Basin.

\section{INTRODUCTION}

In the Silurian and Devonian period, the South Pole was located close to the South American paleoplate margins (Steemans et al. 2008, Breuer et al. 2017). This paleogeographic setting resulted in extensive glaciers formation in the South Pole region, which affects some South American basins, including the Amazonas Basin. Subsequently, large sea transgressions occurred and invaded part of the emerged areas of the supercontinent Gondwana (Carozzi et al. 1973, Johnson 2006, Díaz-Martínez and Grahn 2007). Gondwana was in high latitudes during the Lower Paleozoic, which made its seas cold and, thus, the deposition of siliciclastic rocks in detriment of calcareous formations can be explained (Almeida and Carneiro 2004). It was in this paleogeographic context that the sediments that form the Manacapuru Formation were deposited.

In Brazil, paleontological studies in Silurian-Devonian rocks are numerous; however, in the Amazonas Basin, these investigations are few and based mainly on subsurface data, particularly for palynological surveys (a historical review is given in Grahn 1992), while surface ones are related to ichnology (Nogueira et al. 1999, Matsuda et al. 2010, Gonçalves et al. 2017).

Grahn and Melo (2003) presented the chitinozoan taxonomy and biostratigraphy in outcrops along the Urubu, Uatumã and Abacate rivers, in Amazonas State. The authors compared

${ }^{1}$ Universidade Federal do Amazonas - Manaus (AM), Brazil. E-mails: patriciarochageologia@gmail.com,rrsilveira@ufam.edu.br, rcbarbosa@ufam.edu.br

${ }^{*}$ Corresponding author. the results with more intensively investigated areas in Brazil and proposed five chitinozoan assemblages. Reworking was recognized in some sections. Among them, the outcrop named by the authors as Pt. 10 stands out, which is the target section of this study. The site was correlated by the authors to the Upper Manacapuru Formation, Lochkovian in age, supported by the preliminary study of the reference well for the Trombetas Group 1-AM-1-AM and later formalized by Azevedo-Soares and Grahn (2005). This outcrop was also investigated by Steemans et al. (2008). The study of miospore was used as a biostratigraphic tool by the authors, indicating lower Lochkovian age.

Grahn (2005b) also studied outcrops and wells in the Amazon Basin, using the 1-AM-1-AM well as a reference and identified seven assemblages of chitinozoa, related to the Pitinga, Manacapuru and Maecuru Formations. In the Trombetas River region, the Manacapuru Formation is of early Pridoli age, but the unit can reach upperLudlow age in the Urubu River area (Grahn and Melo 2003).

In this work a systematic lithofaciological and palynological (based on chitinozoan group) study of Manacapuru Formation rocks, Silurian-Devonian in age, is presented, aiming to contribute with questions regarding paleoenvironmental understanding of the unit and its chronostratigraphic position. The outcrop is located at kilometer 982 (former km 99) on BR-174 highway, which connects the cities of Manaus (Amazonas) and Boa Vista (Roraima) (Fig. 1A).

\section{THE AMAZONAS SEDIMENTARY BASIN AND THE MANACAPURU FORMATION}

The Amazonas Basin has an approximate area of 480,000 $\mathrm{km}^{2}$ and covers part of the states of Amazonas and Pará (Fig. 1B). 
According to Teixeira (2001), the sedimentary filling began with the sediments of the Prosperança and Acari Formation deposited in the rift phase of the basin during the Cambrian. However, the age of Purus Group sediments is not consensus. For Cunha (2000) the sediments of the Prosperança (alluvial and fluvial sandstones) and Acari (tidal plateau carbonates) formations were deposited prior to the basin implantation, in the final stages of the Brazilian cycle in late post-orogenic conditions. According to Cunha et al. (2007) the current stratigraphic framework of the basin presents two first-order mega sequences, one Paleozoic and another Meso-Cenozoic.

The former is marked by eustatic variations of sea level and a large volume of Mesozoic diabase dikes and sills intrusions, and can be subdivided into four sequences of second order: Ordovician-Devonian, Devonian-Tournaisian, Neovisean, and Pennsylvanian-Permian Sequence. In this study, part of the Ordovician-Devonian Sequence was analyzed, which was deposited at the Trombetas Group (Caputo 1984). This is composed, from base to top, by the formations of: Autás-Mirim, Nhamundá, Pitinga, Manacapuru and Jatapu.

The Manacapuru Member was elevated to the formation category by Caputo (1984). According to Cunha (2000), this unit is characterized by fine to medium sandstones interbedded with grayish and laminated mudstones, which occur alternately to layers of shale, with fossiliferous content composed mainly of chitinozoan, graptolites, acritarch, sporomorphs (Grahn 1992, Grahn and Paris 1992, Grahn and Melo 2003, Melo and Loboziak 2003, Cardoso and Rodrigues 2005, Steemans et al. 2008) and brachiopods (Tomassi et al. 2015).

The sedimentary fill is a record of sea level oscillations (Cunha et al.2007), where a general regression with some transgressive oscillations allowed sedimentation in the deltaic, coastal, shoreface and offshore environments (Carozzi et al. 1973, Caputo 1984).

\section{MATERIALS AND METHODS}

The lithofaciological analysis was performed in an outcrop (Fig. 1) along BR-174 Highway, on the Urubu River banks with geographical coordinates $02^{\circ} 06^{\prime} 45.5^{\prime \prime} \mathrm{S}$ and 5959'31.0” W. The outcrop was described based on the elaboration of a vertical profile, according to a scheme proposed by Walker (1992).

For the palynological analysis, mainly pelitic layers were collected, which are common in the outcrop. In total, 27 samples were collected. Sampling was done from the base to the top of the section and named from AM1 to AM27. The weighing and grinding of the samples were carried out at the Geochemistry Laboratory of the Amazonas Federal University (UFAM) and then sent to organic palynological processing.

The palynological processing was done at the Marleni Marques Toigo Palynology Laboratory (LPMMT) of the Federal

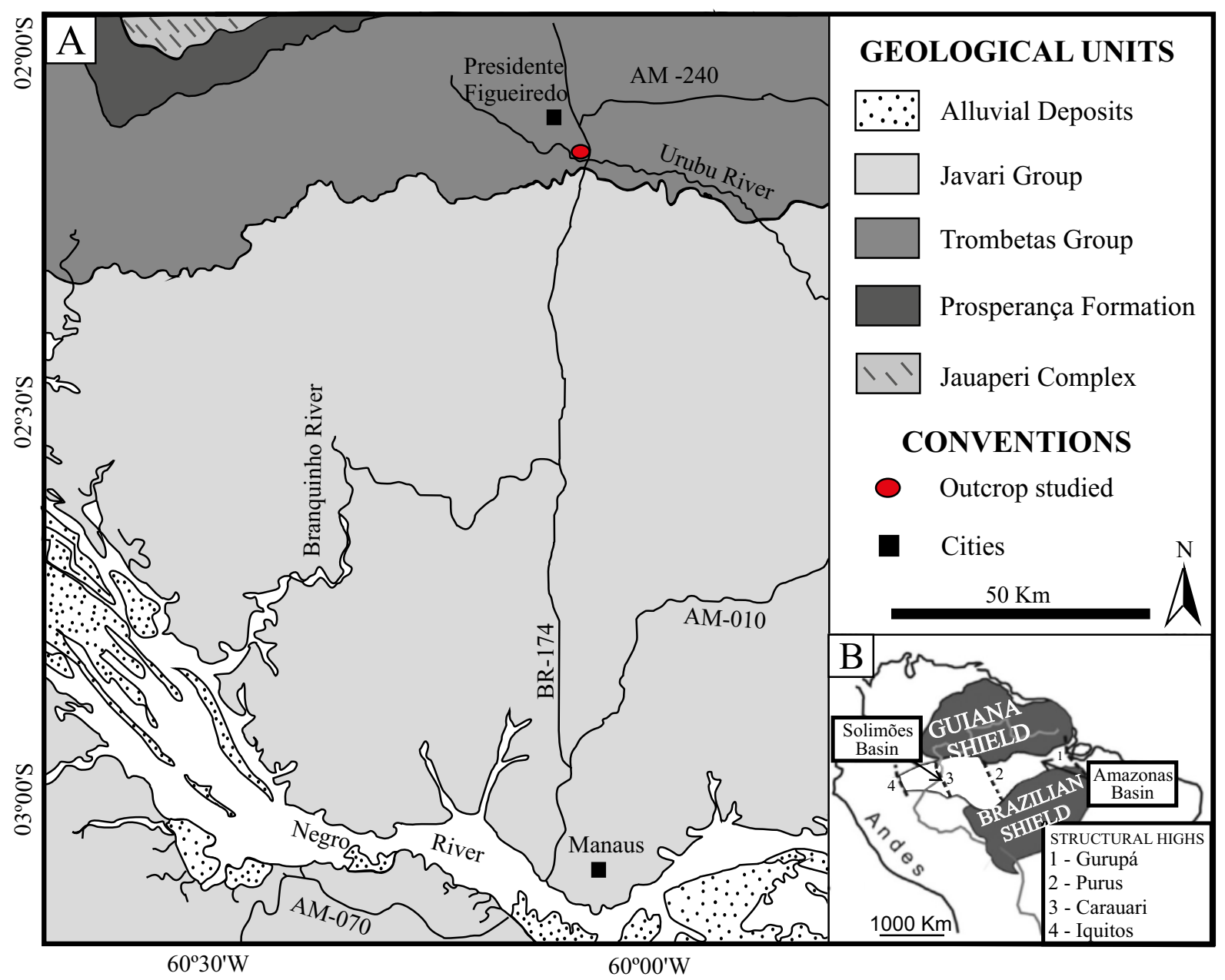

Figure 1. (A) Location and geological map of the region where the outcrop is located (modified from Souza and Nogueira 2009). (B) Location of the Amazon Basin and its regional boundaries. 
University of Rio Grande do Sul and consisted of successive attack steps with acidic reagents $(\mathrm{HCl}$ and $\mathrm{HF})$ in order to remove the inorganic fraction of the samples, according to the procedure described in Wood et al. (1996). Eighty-one palynological slides were made, three of them for each sampled level. The slides were deposited at the Paleontology Laboratory of UFAM under MP-P 13327 at MP-P 13359 coding. The analysis of the palynological slides was performed using a binocular microscope at the Microscopy Laboratory of UFAM.

\section{SEDIMENTARY LITHOFACIES}

The analysed sedimentary rocks of the Manacapuru Formation are located on BR-174 federal highway (Fig. 1) and are below and in abrupt contact with argillite of the Alter do Chão Formation, of Cenozoic age.

The Manacapuru Formation is represented by predominantly clay lithotypes with fine to very fine-grained sandstone interbedded, which surface with a maximum thickness of approximately $7 \mathrm{~m}$ and are laterally continuous for up to $65 \mathrm{~m}$ (Fig. 2). The rocks show yellowish coloration, greyish to reddish, and are friable and intensely oxidized. However, the sedimentary structures are well preserved, especially in sandstones.

The muddy and sandy lithofacies are composed mainly of lenticular bodies. However, the interbedded sandy lithofacies occur in discontinuous lenses form, which exhibit lateral thickening and thinning (pinch-and-swell bedding) and can reach
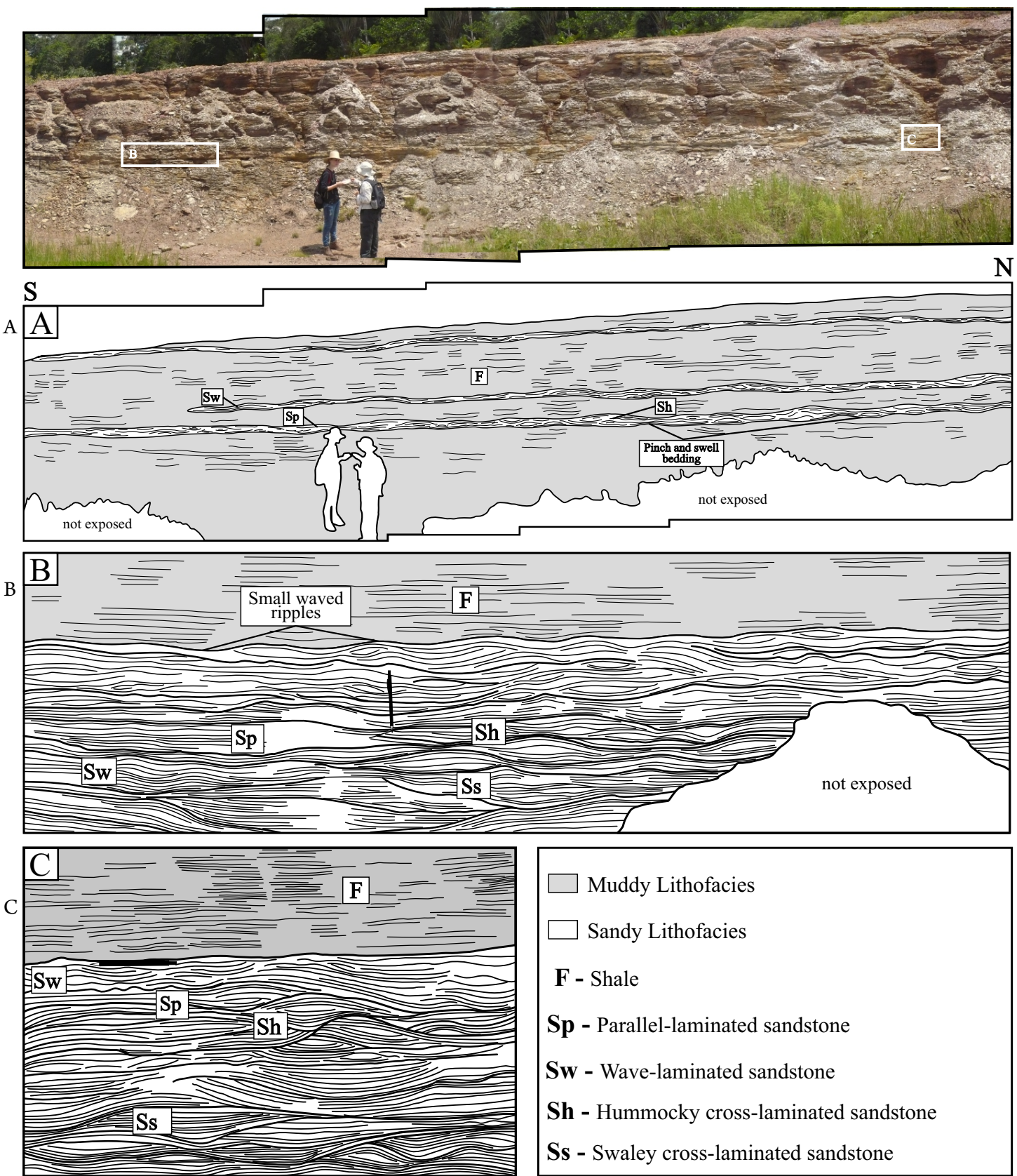

Figure 2. General appearance and details of the Manacapuru Formation exposure target of the investigation. (A) Section interpreted with emphasis on the depositional geometry of the unit, represented by muddy layers (lithofacies $\mathrm{F}$ and $\mathrm{Mm}$ ) with sandy lenses interbedded with pinch-and-sweel bedding, internally structured with the litofácies Sp, Sw, Sh and Ss. (B and C) Detail of contact relations and the lithofacies in the sandstone lenses interbedded with muddy beds. 
a thickness of up to $70 \mathrm{~cm}$ (Fig. 2A). Additionally, sandstone lenses have a slightly erosive base and wavy top.

Lithofaciological analysis carried out in this work allowed the construction of a composite stratigraphic column and defined six sedimentary lithofacies, namely: massive mudstone ( $\mathrm{Mm})$, shale $(\mathrm{F})$, fine to very fine-grained sandstone with plan-parallel lamination ( $\mathrm{Sp}$ ), fine to very fine-grained sandstone with wave lamination $(\mathrm{Sw})$, fine to very fine-grained sandstone with swaley cross-lamination (Ss) and fine to very fine-grained sandstone with hummocky cross-lamination (Sh), comprised in a marine platform under the action of storm waves (Fig. 3).

\section{Massive Mudstone Lithofacies (Mm)}

Mm lithofacies occur in a lenticular layer form, dark grey color, with thickness varying from 20 to $70 \mathrm{~cm}$ and massive structure (Figs. 2,3 and 4). In an isolated way, this lithofacies is intruded by vertical features up to $3 \mathrm{~cm}$ long and filled by very fine sandstone that increase in thickness in the upper portion, forming sub-horizontal lenses up to $7 \mathrm{~cm}$ in length and maximum thickness of $1 \mathrm{~cm}$ (Fig.4A).
In this lithofacies, simple and isolated endichnial tubular features occur uniformly distributed, horizontally to oblique oriented in relation to bedding and with very fine massive sandstone filling (Fig. 4A). In longitudinal sections, its length varies between 0.8 and $3 \mathrm{~cm}$, while in cross sections they have circular to semi-circular shapes of up to $0.8 \mathrm{~cm}$ in diameter.

\section{Sedimentary process}

Mudstone lenticular layers are compatible with deposition with absence of traction and dominated by fall-out processes of clay granulometry particles in suspension. Additionally, the massive structure may be linked to granulometric contrast absence or even to intense weathering (Potter et al. 2005). Massive fine-grained sandstone occurring in $\mathrm{Mm}$ lithofacies are related to restricted processes of total liquefaction and injection of water supersaturated sediments directed to areas of lower pressure (Owen 2003). The massive filling of the intrusion coincides with this interpretation.

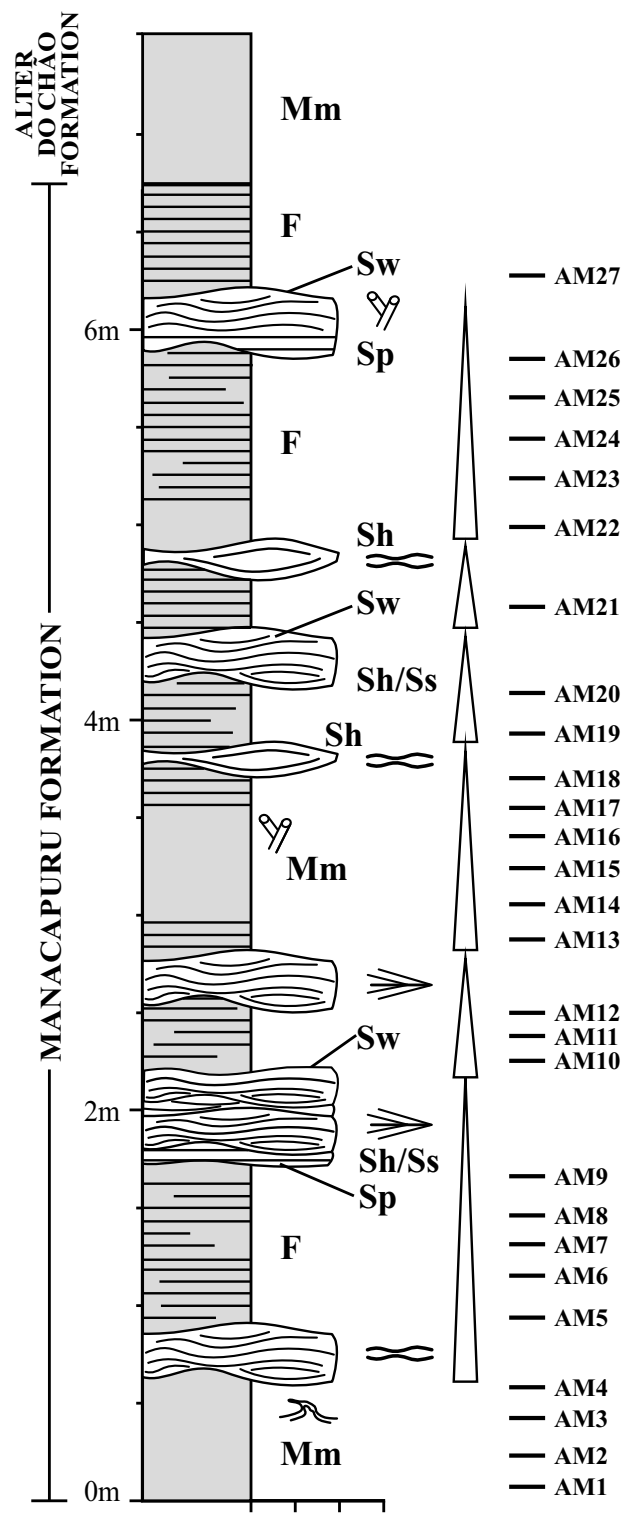

Massive bedding

Fissility

Planar bedding

Wave bedding

Hummocky to-Swaley cross-bedding

$\approx$ Pinch-and-swell lamination

$\geqslant$ Low-angle truncation

ح欠 Sandstone dikes

ly Trace Fossil

$\triangle$ Shallowing-upward cycle

\section{- Samples}

\section{Lithofacies}

F - Shale

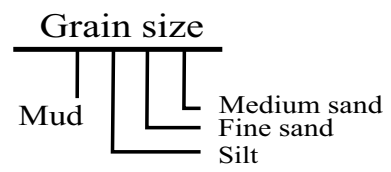

Mm - Massive mudstone

Sp - Parallel-laminated sandstone

Sw - Wave-laminated sandstone

Sh - Hummocky cross-laminated sandstone

Ss - Swaley cross-laminated sandstone

Figure 3. Composite columnar section of the Manacapuru Formation on federal highway BR 174 with sedimentary lithofacies defined and interpreted in this study. Rocks of this unit are below and in abrupt contact by argillite of the Alter do Chão Formation, of Cenozoic age. 


\section{Shale Lithofacies (F)}

Lithofacies $\mathrm{F}$ is the most representative of the outcrop, composed of dark grey lenticular bodies that reach a maximum thickness of $1 \mathrm{~m}$ and are laterally continuous for more than $50 \mathrm{~m}$. The lower contact of this lithofacies conform to waved sandstone lenses (described below), while the upper limit is slightly erosive. Internally, it presents fissility planes, sometimes incipient, and slightly waved with up to $2 \mathrm{~mm}$ of thickness (Figs. 2B, 2C and 3). Remains and molds of inarticulate and fragmented brachiopods make up the macrofossil content. Brachiopods have length and width between 1.5 and $2.5 \mathrm{~cm}$, and 1.4 and $2.2 \mathrm{~cm}$, respectively. It is possible to observe the organisms well marked growth lines in the specimens found. They have a circular to elongated outline and are related to the Lingulidae (Figs. 4B, 4C and 4D).

\section{Sedimentary process}

Lenticular and laterally continuous shales layers are traditionally bound to depositional sites with tractionless processes and dominated by clay-sized particles deposition related to fallout process under low energy conditions. However, slightly wavy fissile planes suggest incipient performance of basin processes related to oscillatory flow (Schieber et al.2007, Schieber and Southard 2009, Schieber 2011).

\section{Parallel-laminated Sandstone Lithofacies (Sp)}

This lithofacies occurs in the form of grey to yellowish lenticular bodies, up to $15 \mathrm{~cm}$ thick, laterally restricted and composed of fine to very fine-grained sandstones, with rounded and well selected grains (Figs. 2 and 3). Internally, they are structured with plane-parallel lamination with millimetric foresets organized in sets of up to $7 \mathrm{~cm}$ thick (Figs. $2 \mathrm{~B}$ and $2 \mathrm{C}$ ). Lower and upper contact relationships with other sandy lithofacies are usually erosive.

\section{Sedimentary Process}

Sp lithofacies formation may be related to the migration of sandy bed forms in both the unidirectional and the combined flow. In the first example, it refers to the process of sand-bed migration (sandsheets) in streams under upper-flow (Miall 2006, Nichols et al.2007). On the other hand, when associated to combined flows, it is the result of sandy grains migration in flat beds form related to a greater contribution of the unidirectional component (Dumas and Arnott 2006, Plint 2010). The absence of streams in the associated sandstone lithofacies is consistent with the second interpretation.

\section{Wave Laminated Sandstone Lithofacies (Sw)}

Sw lithofacies exhibit grey to yellowish lenticular bodies. They reach up to $16 \mathrm{~cm}$ thick and are laterally continuous for up to $15 \mathrm{~m}$, being most frequently found on top of sandstone lenses interbedded in F lithofacies (Figs. 2 and 3). They are composed of fine to very fine-grained sandstones with rounded and well selected grains, structured with waved lamination with 15 and $4 \mathrm{~cm}$ maximum length and width, respectively. The millimetric foresets are organized in wavy sets of up to $8 \mathrm{~cm}$ that locally develop erosive bases (Figs. 2B and 2C).
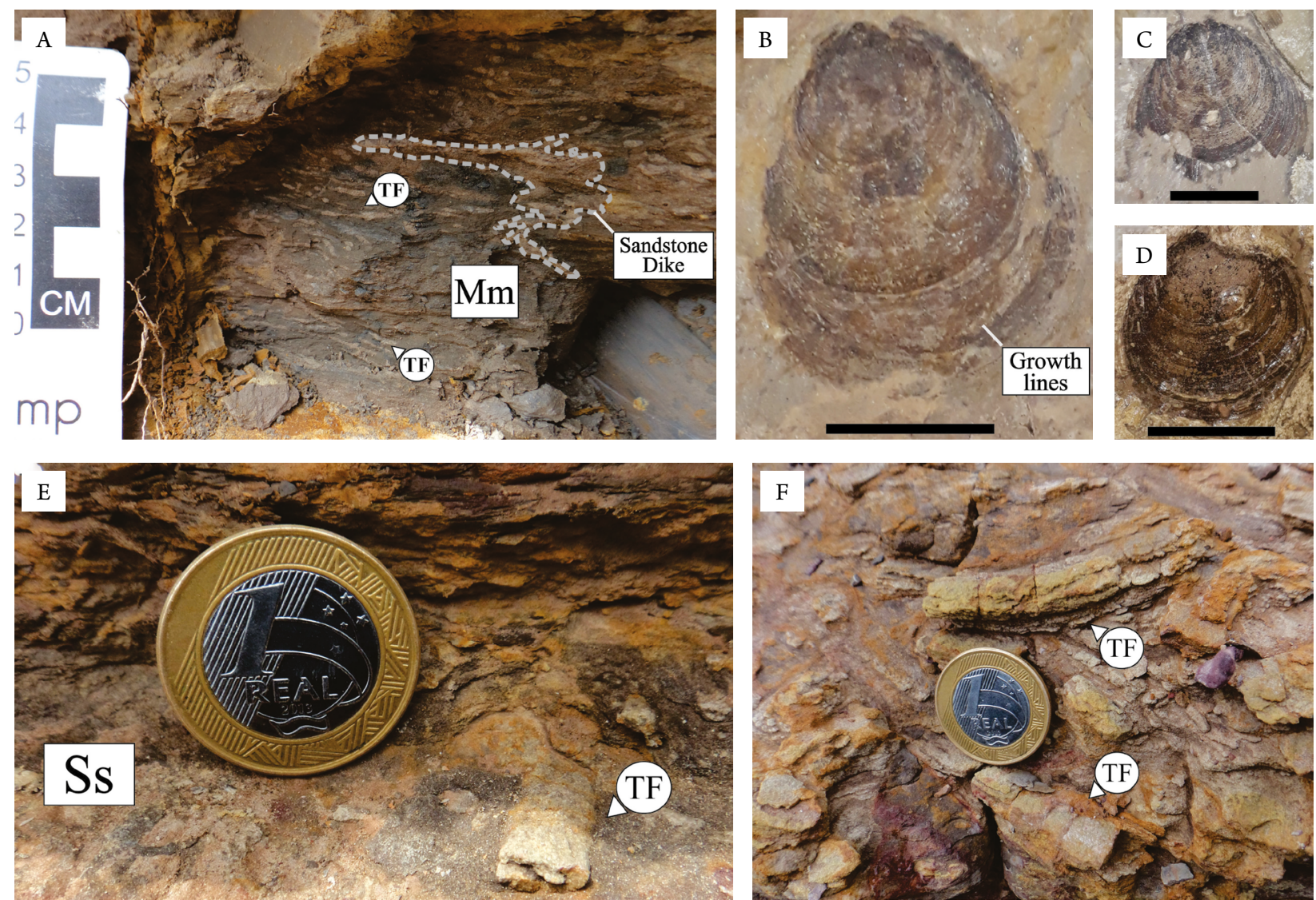

Figure 4. Main details feature of the Manacapuru Formation sedimentary lithofacies evaluated in this work. (A) Massive mustone (Mm) with endichnial trace fossil (TF) and massive sandstone dike. (B, C and D) Remains and moulds of Lingulida brachiopods found in F lithofacies and their evident growth lines. The scale bar represents $1 \mathrm{~cm}$. E, F. Horizontal and oblique trace fossil that occur associated with the lithofacies $S \mathrm{~s}$. 


\section{Sedimentary process}

Fine to very fine wavylaminated sandstones are related to sandy bed forms migration associated to oscillatory currents under shallow water depth hydrodynamic conditions (Dumas and Arnott 2006, Nichols et al. 2007). The base of the waved Sw lithofacies sets with locally erosive character, together with the high ratio between the length and width of the foresets reinforce this proposal.

\section{Swaley Cross-laminated Sandstone Lithofacies (Ss)}

Ss lithofacies are characterized by greyish to yellowish lenticular layers, composed of fine to very fine-grained sandstones with rounded and well selected grains, up to $12 \mathrm{~cm}$ thick and laterally continuous for more than $10 \mathrm{~m}$ (Figs. 2 and 3 ). They exhibit swaley cross lamination with millimetric foresets, arranged in sets of up to $7 \mathrm{~cm}$ with concave, slightly excavated and asymmetric bases which laterally gradate to $\mathrm{Sw}$ or Sh lithofacies, described later (Figs. 2B and 2C).

The observable fossiliferous content in Ss lithofacies is concentrated in the upper portion of the bed and are described as predominantly horizontal to oblique trace fossil in relation to the bedding, simple and slightly sinuous, ranging from endichnial to exichnial, without branching and intercrossed (Figs. 4E and 4F). They are tubular features without active filling, internally massive and with the same texture of the host rock. The outer portion of the tube is smooth and without ornamentation, however trace fossil occurs with external wall with apparent longitudinal groove. Trace fossils are between 2 and $8 \mathrm{~cm}$ in length, which in cross sections show semi-circular to elliptical forms with a maximum diameter of $1.5 \mathrm{~cm}$.

\section{Sedimentary process}

Fine to very fine-grained sandstone with wavy sets and asymmetric erosive bases structured with swaley cross lamination are associated to erosion and filling features of the sandy substrate by dunes influenced by combined flow, with unidirectional component predominance over the oscillatory, related to the energy decline phase of the storm events (Cheel and Leckie 1993, Dumas and Arnott 2006, Plint 2010). The lateral association with lithofacies related to oscillatory and unidirectional flow, Sh and Sp lithofacies respectively, which are compatible with lateral changes in the hydrodynamical conditions of the bed forms, traditionally attributed to storm stream (Plint 2010).

\section{Hummocky Cross-laminated Sandstone Lithofacies (Sh)}

This lithofacies is composed of yellowish to greyish lenticular bodies of fine to very fine-grained sandstone, with rounded and well selected grains, presenting maximum thickness of $15 \mathrm{~cm}$ and are laterally continuous for more than $12 \mathrm{~m}$ (Figs. 2 and 3). Sh lithofacies are organized in wavy sets of up to $10 \mathrm{~cm}$ thick, with concave and slightly erosive base, where symmetrical shapes predominate. Internally to the sets, isotropic to anisotropic hummocky cross-laminations occur, with an $85 \mathrm{~cm}$ maximum wavelength and a $7 \mathrm{~cm}$ width, with inclined foresets with angles smaller than $8^{\circ}$ that develop low angle truncations. Laterally, Sh lithofacies gradate from planar to wavy laminations ( $\mathrm{Sp}$ and $\mathrm{Sw}$ lithofacies) (Figs. 2B and 2C).
The fossiliferous content associated with Sh lithofacies is represented by trace fossils in the form of endichnial to exichnial tubes, horizontal to oblique in relation to the bedding and concentrated in the upper portion of the layers, like those described in Ss lithofacies.

\section{Sedimentary process}

Fine to very fine-grained sandstone with isotropic to anisotropic hummocky cross-lamination are compatible with the migration of dunes under combined flow, with predominance of the oscillatory component under the unidirectional, related to storm events in marine shelves (Arnott and Southard 1990, Cheel and Leckie 1993). The lateral gradation for the plane and wavy lithofacies is related to the decrease of the oscillatory component and increase of the unidirectional currents acting with the storm energy decline (Dumas and Arnott 2006).

\section{PALYNOLOGY}

The 27 stratigraphic levels sampled showed satisfactory palynological results, with different concentrations and degrees of palynomorph preservation. In general, the samples are fertile, with diverse and abundant palynological content. The most representative groups of the recovered association are the acritarch followed by the chitinozoan, which reinforces the marine character of the assemblage. Subordinately, there is occurrence of miospore, scolecondont and fungus spore. There is a significant amount of amorphous organic matter, which in some cases makes it difficult to visualize the diagnostic characters of the chitinozoan.

In relation to chitinozoan, it was possible to identify them at a generic and specific level. These organisms occur predominantly as isolated tests and less commonly in short chains.

All chitinozoan genera and species recovered in the studied outcrop are alphabetically listed in Table 1 by genus and species.

The photomicrographs of the organisms recovered are shown in the Figures 5, 6, 7 and 8, and the information about its respective provenance are shown in the Figure 9.

\section{PALAEOENVIRONMENTAL RECONSTRUCTION}

In the Mm lithofacies there is the presence of tubular structures that are related to trace fossils of feeding produced by the vermiform organism activity that excavated the rich muddy substrate and generated active filling of the tunnels, features compatible with the ichnogenus Planolites and Thalassinoides (Pemberton and Frey 1984, Seilacher 2007).

Lingulida brachiopods occur in the lithofacies F. Their living and fossil specimens inhabit or inhabited in greater abundance regions of continental shelf and upper slope, approximately between 50 and $500 \mathrm{~m}$ deep (Clarkson 2007, Alvarez and Chácon 2009). Specifically, these organisms preferentially colonized the shallow epicontinental seas in the Paleozoic (Fonseca 2004). The recognition of these lingulids indicates that the muddy substratum was partially colonized by these organisms, which are infaunal, benthic and exclusively marine 
(Fonseca 2004, Alvarez and Chacón 2009), considering an autochthonous assemblage. If the organisms in question are allochthonous, storm events could be responsible for transporting the organisms. Trace fossil is predominantly horizontal and concentrated at the top of the lithofacies (Ss and Sh), with absence of branching and ornamentation, besides the passive filling with massive structure and textually like the matrix rock are compatible with the ichnogenus Paleophycus (Keighley and
Pickerill 1995). These traces are related to habitat and/or feeding records related to soft body organisms (nemathelminths) with suspensivorous habits and/or predators that used the sandy substrate for habitation after the storm event (Pemberton and Frey 1984, Seilacher 2007). All these ichnogenera occur in the Cruziana ichnofacies (Fernandes et al. 2002).

From the stratigraphic aspect, it is possible to observe that laterally continuous layers composed of muddy lithofacies (F and Mm)

Table 1. Relation of recovered chitinozoan and their respective locations on the figures.

\begin{tabular}{|c|c|}
\hline Taxon & Figure \\
\hline Ancyrochitina fragilis Eisenack 1955 & Fig. 5.1 \\
\hline Ancyrochitina aff. A. tomentosa Taugourdeau and Jekhowsky 1960 & Fig. 5.2 \\
\hline Ancyrochitina cf. A. brevis Taugourdeau and Jekhowsky 1960 & Fig. 5.3 \\
\hline Ancyrochitina ex. gr. A. ancyrea Eisenack 1931 & Fig. 5.4 \\
\hline Ancyrochitina ex. gr. A. gutnica Laufeld 1974 & Fig. 5.5 \\
\hline Ancyrochitina? ex. gr. A. floris Jaglin 1986 & Fig. 5.6 \\
\hline Ancyrochitina sp. A sensu Grahn and Melo 2003 & Fig. 5.7 \\
\hline Angochitina echinata Eisenack 1931 & Fig. 5.8 \\
\hline Angochitina elongata Eisenack 1931 & Fig. 5.9 \\
\hline Angochitina filosa Eisenack 1955 & Fig. 5.10 \\
\hline Angochitina sp. aff. A. cyrenaicensis Paris 1988 sensu Grahn and Paris 1992 & Fig. 5.11 \\
\hline Angochitina sp. aff. A. mourai Schweineberg 1987 sensu Grahn and Melo 2003 & Fig. 6.1 \\
\hline Angochitina sp. B sensu Grahn 2005a & Fig. 6.2 \\
\hline Angochitina? sp. sensu Grahn and Paris 1992 & Fig. 6.3, 6.4 \\
\hline Armigutta urubuense Grahn and Melo 2003 & Fig. 6.5, 6.6 \\
\hline Belonechitina cf. B. sp. A sensu Grahn 2005a & Fig. 5.12 \\
\hline Bursachitina sp. A sensu Grahn and Melo 2003 & Fig. 5.13 \\
\hline Cingulochitina ervensis Paris 1979 in Paris 1981 & Fig. 6.7 \\
\hline Cingulochitina serrata Taugourdeau and Jekhowsky 1960 & Fig. 6.8, 6.9 \\
\hline Cingulochitina wronai Paris and Kriz 1984 & Fig. 6.10 \\
\hline Cingulochitina aff. C. serrata Taugordeau and Jekhowsky 1960 & Fig. 6.11, 6.12 \\
\hline Conochitina gordonensis Cramer 1964 & Fig. $6.13,6,14$ \\
\hline Conochitina pachycephala Eisenack 1964 & Fig. 6.15 \\
\hline Conochitina tuba Eisenack 1932 & Fig. 6.16 \\
\hline Desmochitina cortesiana Schweineberg 1987 & Fig. 7.1 \\
\hline Eisenackitina granulata Cramer 1964 & Fig. $7.2,7.3$ \\
\hline Eisenackitina cf. E. bohemica Eisenack 1934 & Fig. $7.4,7.5$ \\
\hline Fungochitina kosovensis Paris 1981 & Fig. 7.6 \\
\hline Hoegisphaera sp. A & Fig. 7.7 \\
\hline Lagenochitina navicula Taugourdeau and Jekhowsky 1960 & Fig. 7.8 \\
\hline Linochitina sp. A sensu Grahn and Melo 2003 & Fig. 7.9 \\
\hline Plectochitina carminae Cramer 1964 & Fig. $7.10,7.11$ \\
\hline Pterochitina megavelata Boumendjel 2002 & Fig. $7.12,7.13$ \\
\hline Pterochitina perivelata Eisenack 1937 & Fig. $7.14,7.15$ \\
\hline Ramochitina bjornsundquisti Grahn and Melo 2003 & Fig. $7.16,7.17$ \\
\hline Ramochitina sp. sensu Grahn and Paris 1992 & Fig. 7.18 \\
\hline Saharochitina gomphos Grahn and Melo 2003 & Fig. 7.19 \\
\hline Saharochitina sp. A & Fig. 7.20 \\
\hline Sphaerochitina acanthifera Eisenack 1955 & Fig. 8.1, 8.2 \\
\hline Sphaerochitina sphaerocephala Eisenack 1932 & Fig. 8.3, 8.4 \\
\hline Vinnalochitina corinnae Jaglin 1986 & Fig. 8.5 \\
\hline
\end{tabular}


refer to planar deposition sites, with low energy, absence of traction currents and dominated by fine particle fall-out processes (Reineck and Singh 1980, Potter et al. 2005). However, the presence of fine to very fine-grained sandstones lenses interbedded in lithofacies $\mathrm{F}$, formed by the action of oscillatory (Sw lithofacies) and combined (Sp, Ss and Sh lithofacies) flows, suggests that deposition sites dominated by fall-out processes were eventually supplanted by the acting of basins currents, represented here by the action of storm waves (Cheel and Leckie 1993, Dumas and Arnott 2006).

Sandstone lithofacies exhibiting thickening and thinning lateral patterns (pinch-and-swell bedding) reinforce the interpretation of remobilization and erosion of sandy sediments associated with wave acting (Arnott and Southard 1990).

In storm events, increased wavelengths influenced by increased wind velocities produce two distinct conditions:

1. intensifies the rip current that carry shoreface sediments to offshore;

2. shifts the wave-base level to deeper regions (Plint 2010).

Thus, shales with interbedded sandstones generated predominantly by combined flow form shallowing upward metric cycles in the marine shelf associated to storm events.

Under these conditions, fine to very fine sand sediments carried by rip current and then available to deeper regions could
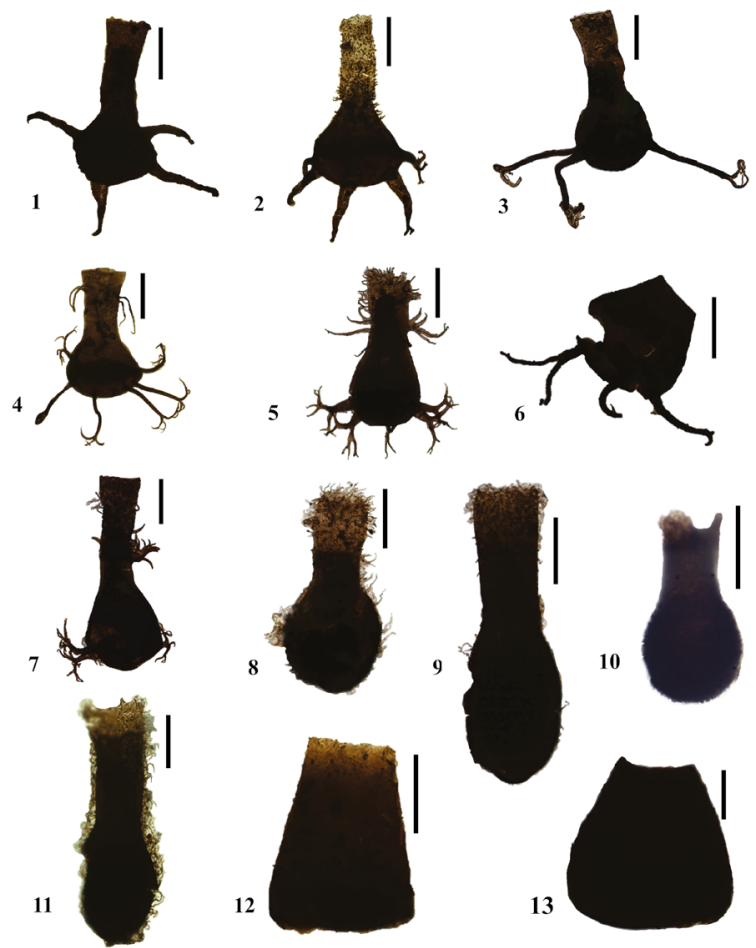

1: Ancyrochitina fragilis (13342, E30); 2: Ancyrochitina aff. A. tomentosa (13339, O35-3); 3: Ancyrochitina cf. A. brevis (13285, P49-2); 4: Ancyrochitina ex. gr. A. ancyrea (13323, S54-3); 5: Ancyrochitina ex. gr. A. gutnica (13300, S33); 6: Ancyrochitina? ex. gr. floris (13279, R29); 7: Ancyrochitina sp. A (13288, P50); 8: Angochitina echinata (13303, S50); 9: Angochitina elongata (13306, X48); 10: Angochitina filosa (13312, Q30); 11: Angochitina sp. aff. A. cyrenaicensis (13345, X61-4); 12: Belonechitina cf. B. sp. A (13351, P38-3); 13: Bursachitina sp. A (13310, Q47-1).

Figure 5. Chitinozoan from outcrop of Manacapuru Formation. The scale bar represents $50 \mu \mathrm{m}$. In parentheses, slide and location in the England Finder and more informations see Table 1. still be remobilized by combined flow (Dumas and Arnott 2006, Della Fávera 2008). Additionally, the sandy sediments input by return streams over offshore clays could also induce total liquefaction processes (massive structure) and injection of sediments found in Mm lithofacies (Nichols et al. 2007, Plint 2010).

With the storm energy decline, the wavelength decreases and the base level returns to fair weather conditions, and thus sandy sediments were reworked by vermiform organisms. Layers of lithofacies F with waved and concordant basal contact with sandstone lenses reinforce the return of normal sedimentation conditions of suspended muddies that cover the sandy macroform (Della Fávera 2008).

The predominance of muddy lithofacies with interbedded sandstone lenses generated by the combined flow action coincides with deposition sites related to the offshore sub-environment inserted in a shallow-water marine shelf and was influenced by storm events.

There are few publications on environmental control over chitinozoan. Apparently, the occurrence of this organism is minimally controlled by facies (Achab and Paris 2007). It is well known that the group inhabited nearshore and offshore environments, but its greatest diversity occurred in cold waters of high paleolatitudes and upper and lower offshore environments (Laufeld 1974, Grahn and Paris 2011). Shallowing of the shelf is often
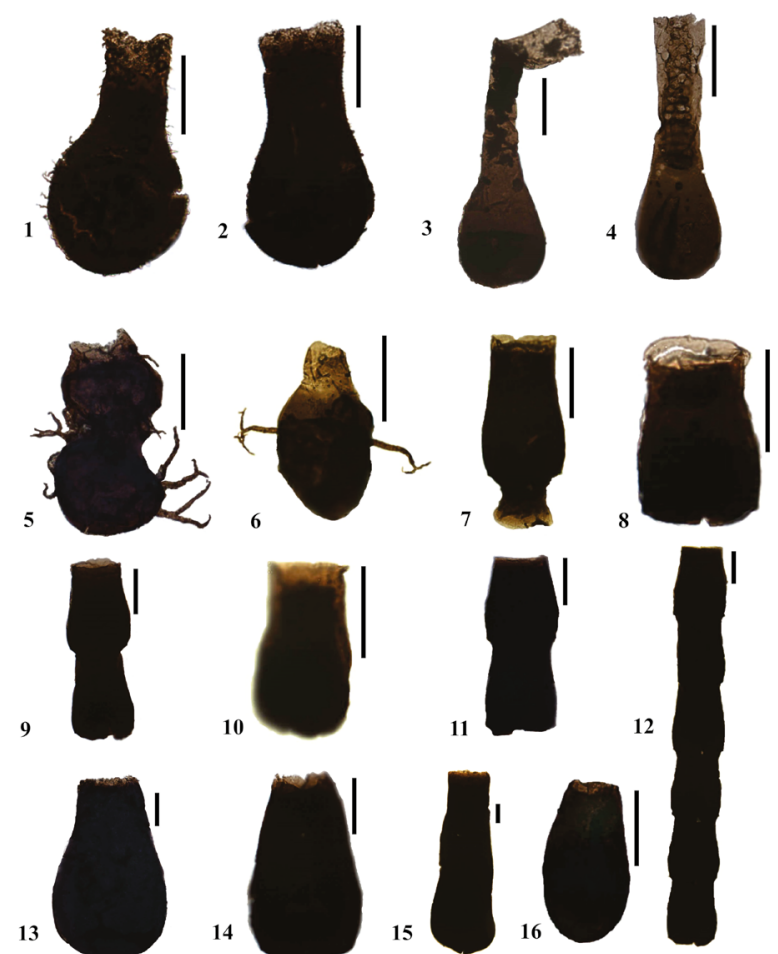

1: Angochitina sp. aff. A. mourai (13291, C57-1); 2: Angochitina sp. B (13311, U35-3); 3, 4: Angochitina? sp. (13280, J34-4; 13358, U51-4); 5, 6: Armigutta urubuense (13311, M59-3; 13351, N53-4); 7: Cingulochitina ervensis (13358, F40); 8, 9: Cingulochitina serrata (13357, E32-2; 13357, P44); 10: Cingulochitina wronai (13359, L49); 11, 12: Cingulochitina aff. C. serrata (13311, F48; 13318, J47); 13, 14: Conochitina gordonensis (13309, V32-1; 13310, U44); 15: Conochitina pachycephala (13332, P50-3); 16: Conochitina tuba (13285, K47).

Figure 6. Chitinozoan from outcrop of Manacapuru Formation. The scale bar represents $50 \mu \mathrm{m}$. In parentheses, slide and location in the England Finder and more informations see Table 1. 
accompanied by increased abundance of chitinozoan, which may be related to an input of terrigenous (Paris 1981). It was not possible to establish a control between the described lithofacies with their respective implications and the distribution of chitinozoan along the profile. This may be related to the intense reworking in the section, as indicated by the palaeofauna recovered and their distribution along the outcrop, or by the small representation of the outcrop for environmental control statements.

The successive storm events, evidenced by the shallowing upward cycles (Fig. 3), may have been responsible for the intense rework observed in the profile. During these events, a large volume of water accumulates in shallow water areas and returns to the platform through return streams, which during this process erode and rework the substrate (Holz and Simões 2002).

\section{AGE}

Regarding the analysis of the chitinozoan, the assemblage reported here belongs to the Upper Manacapuru Formation, according to the correlation to the 1-AM-1-AM reference well, also used by Grahn and Melo (2003) and Grahn (2005b).
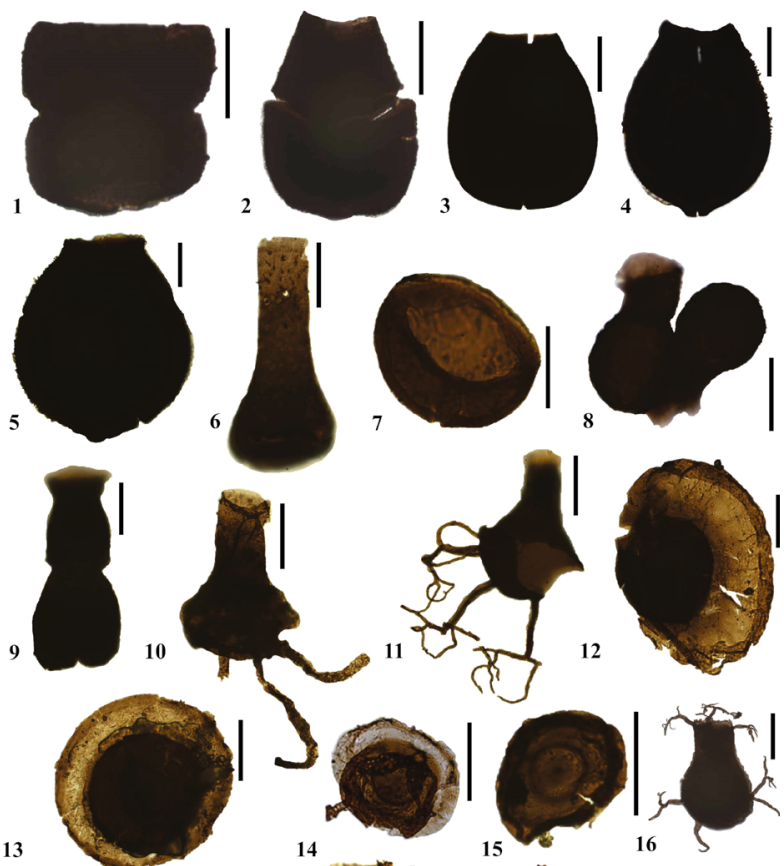
14
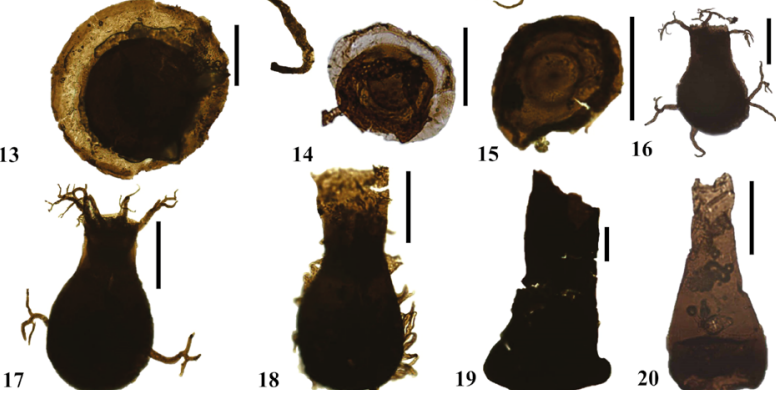

16
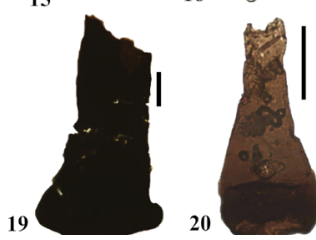

1: Desmochitina cortesiana (13279, F47); 2, 3: Eisenackitina granulata (13280, M38-2; 13337, M39-4); 4, 5: Eisenackitina cf. E. bohemica (13288, G52-1; 13332; N33-3); 6: Fungochitina kosovensis (13359, L44-2); 7 : Hoegisphaera sp. A (13317, M44-4); 8: Lagenochitina navicula (13313, W49-3); 9: Linochitina sp. A (13357, J31-1); 10, 11: Plectochitina carminae (13322, E41; 13352; U53-1); 12, 13: Pterochitina megavelata (13351, M274; 13318, L42); 14, 15: Pterochitina perivelata (13279, P28-4; 13356, F424); 16, 17: Ramochitina bjornsundquisti (13279, U37-2; 13318, Q45-3); 18: Ramochitina sp. (13344, O33); 19: Saharochitina gomphos (13359, L28); 20: Saharochitina sp. A (13280, J43-3).

Figure 7. Chitinozoan from outcrop of Manacapuru Formation. The scale bar represents $50 \mu \mathrm{m}$. In parentheses, slide and location in the England Finder and more informations see Table 1.
Recovered organisms, in general, are well preserved, although some elements are torn or corroded. The Manacapuru Formation in the studied outcrop presents diversity and abundance, with 385 specimens of chitinozoan being recognized along the stratigraphic levels analyzed (Fig. 9). Systematic classification allowed to recognize 41 species, however 18 of them were left in open nomenclature.

Of the 41 recognized taxa, twenty differ from those presented by Grahn and Melo (2003) in the Pt. 10, namely: Ancyrochitina cf. A. brevis, A. aff. A. tomentosa, A.? ex. gr. A.floris, A. sp. A sensu Grahn and Melo 2003, Angochitina elongata, Angochitina sp. aff. A. cyrenaicensis, Armigutta urubuense, Belonechitina cf. B. sp. A sensu Grahn 2005b, Bursachitina sp. A sensu Grahn and Melo 2003, Cingulochitina ervensis, C. aff. C. serrata, Fungochitina kosovensis, Hoegisphaera sp. A, Lagenochitina navicula, Linochitina sp. A sensu Grahn and Melo 2003, Plectochitina carminae, Ramochitina sp. sensu Grahn and Melo 2003, Saharochitina sp. A, Sphaerochitina sphaerocephala and Vinnalochitina corinnae. Among the most diverse forms are the genus Angochitina and Ancyrochitina. Recovered organisms allowed the recognition of reworked faunas with two distinctives ages and one assemblage, younger and which defines the age of the exposure.

In relation to the reworked faunas, it can be stated that one of them is characteristic of the upper Ludlow. Species such as Angochitina elongata, Linochitina sp. A sensu Grahn and Melo 2003, Plectochina carminae and Ramochitina sp. sensu Grahn and Paris 1992 limited the paleofauna to a maximum age of the upper Ludlow (Fig. 10). The joint occurrence of species such as Conochitina gordonensis, Eisenackitina granulata, Pterochitina perivelata, among others, allows to infer Ludfordian age.
1

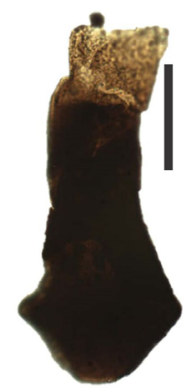

4

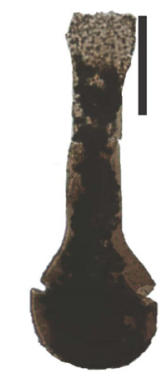

2

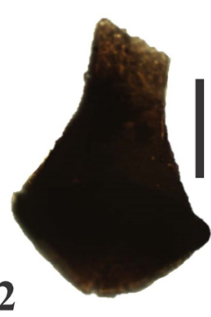

3

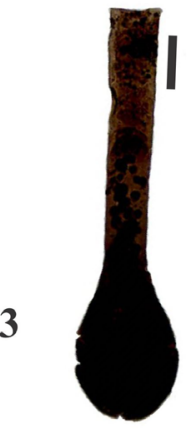

5

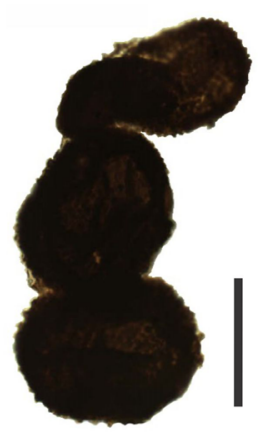

1, 2: Sphaerochitina acanthifera (13326, X47; 13320, H36); 3, 4: Sphaerochitina sphaerocephala (13279, N28-4, 13279, F37-2); 5: Vinnalochitina corinnae (13320, S46-2).

Figure 8. Chitinozoan from outcrop of Manacapuru Formation. The scale bar represents $50 \mu \mathrm{m}$. In parentheses, slide and location in the England Finder and more informations see Table 1. 
The other paleofauna reworked and recognized in the outcrop can be associated with the lower Pridoli (Fig. 10). In it, there is the occurrence of species that have a long-range stratigraphic distribution like Ancyrochitina fragilis and Cingulochitina serrata. Abundant species such as Pterochitina perivelata, Sphaerochitina acanthifera and Sphaerochitina sphaerocephala indicate an age no

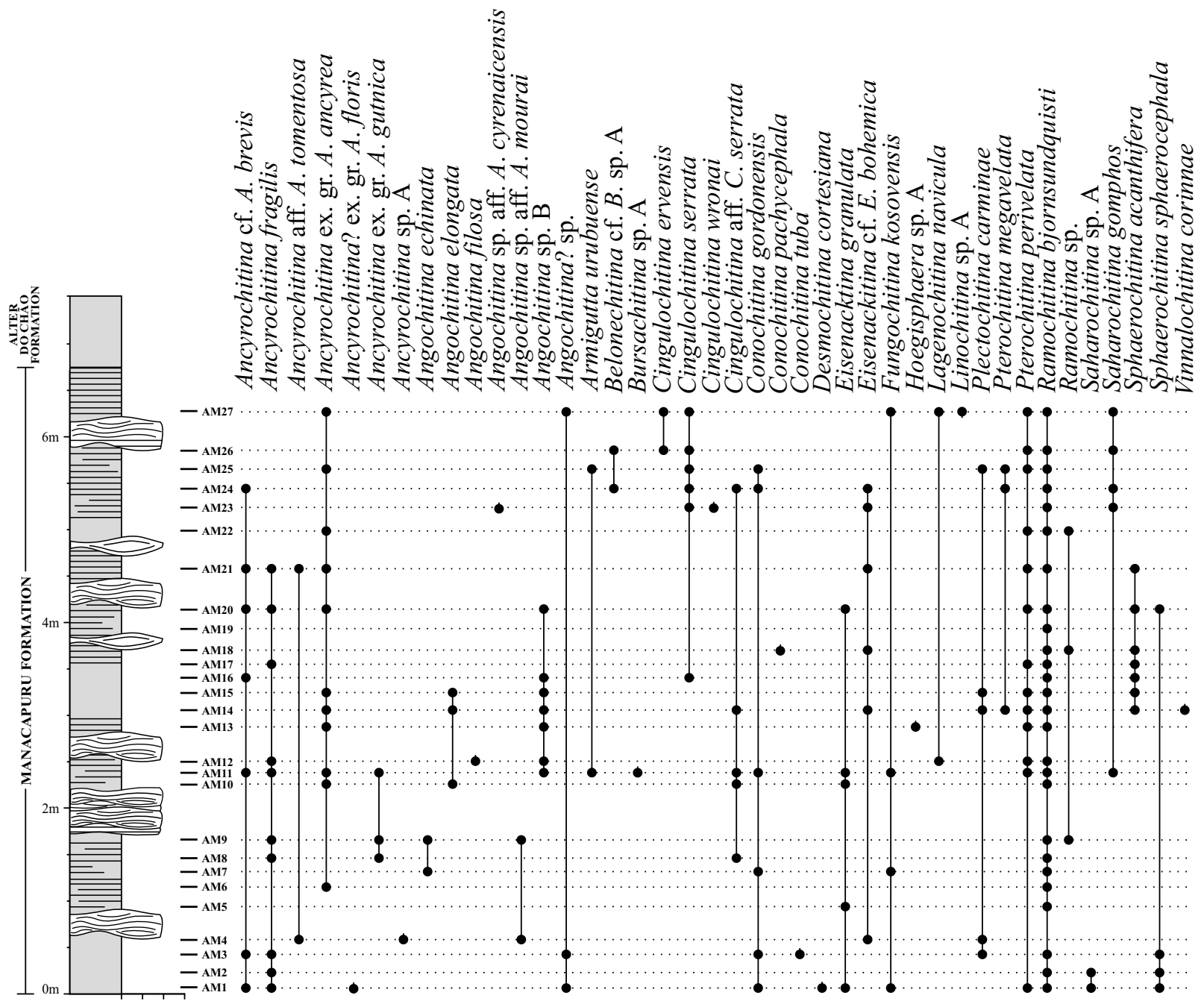

Figure 9. Sampling and stratigraphical distribution of each species recovered along the profile.

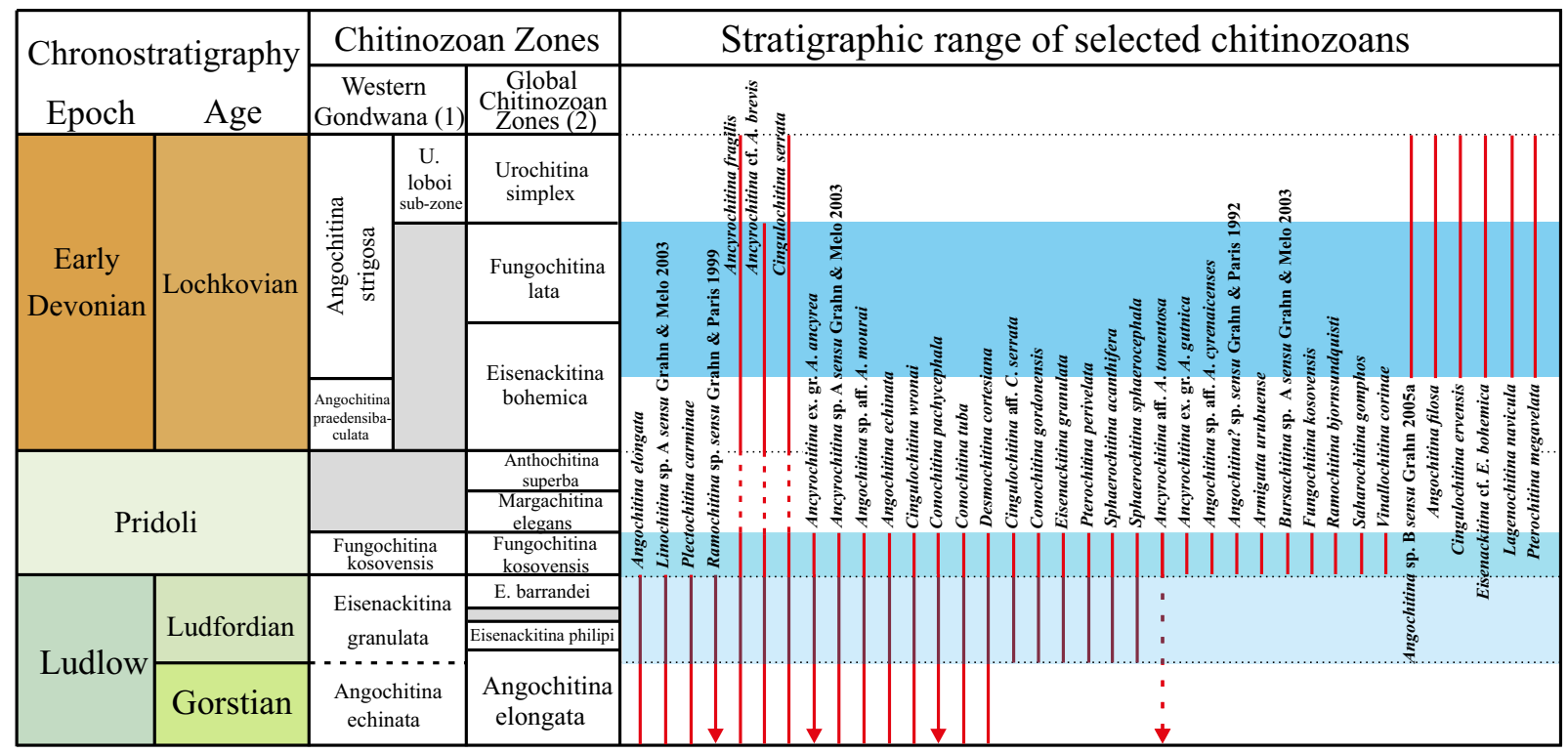

Figure 10. Stratigraphic amplitude of the taxa identified according to literature. (1) Chitinozoan Zones of Western Gondwana according to Grahn (2006) for the Silurian, Grahn (2005a) and Mauller et al. (2009) for the Devonian; (2) Global Chitinozoan Zones according to Verniers et al. (1995) for the Silurian and Paris et al. (2000) for the Devonian Period. 
older than Ludfordian. The occurrence of Angochitina? sp. sensu Grahn and Paris 1992, Ramochitina bjornsundquisti, Saharochitina gomphos, Armigutta urubuense, Vinnalochitina corinnae narrows the age of the reworked paleofauna to the lower Pridoli.

According to the literature, the occurrence of Ramochitina bjornsundquisti is restricted to Pridolian strata. It should be emphasized that it is the most representative quantitative taxa, with 134 of 385 tests attributed only to the species and with a wide stratigraphic distribution in the profile, indicated in 25 of the 27 levels sampled. This expressive occurrence may be the result of intense reworking or it can be considered that the total age span of the specie could extend into the early Lochkovian.

The assemblage identified in the exposure is typical of the lower Lochkovian. Characteristic species are Angochitina filosa, Cingulochitina ervensis, Lagenochitina navicula and Pterochitina megavelata. It also presents long-range species such as Ancyrochitina fragilis, Ancyrochitina cf. brevis and Cingulochitina serrata. It represents the Upper Manacapuru Formation and is within the Angochitina strigosa Total Range Zone of Western Gondwana, proposed by Grahn (2005a) and revised by Mauller et al. (2009). This assemblage is correlated to Assemblage C by Grahn and Melo (2003), Assemblage 7 by Grahn (2005b), and Assemblage VII by Azevedo-Soares (2009).

\section{CONCLUSION}

Six muddy and sandy lithofacies were identified in the outcrop. Muddy lithofacies, resulting from decantation processes, interbedded with the sandstone lenses generated by the combined flow acting indicate that the sedimentation took place in an offshore sub-environment inserted in a shallow-water marine shelf and was constantly influenced by stormy events. Presence of ichnofossils in sandy sediments suggests that, after these events, the substrate was reworked by vermiform organisms.

The palynological analysis allowed the recognition of an assemblage of chitinozoan attributed to the lower Lochkovian, which reaffirms what was proposed in other works in the place. There is an intense reworking, evidenced by the occurrence of paleofaunas with Ludfordian to Pridolian ages. Although no faciological control has been observed on the occurrence and distribution of the chitinozoa along the profile, it is possible that the intense reworking observed in the section is due to the constant storm events evidenced by the shallowing upward cycles and other observed structures.

\section{ACKNOWLEDGEMENTS}

The authors would like to thank CAPES for funding the field activities and for granting a master's scholarship (for the first author), Marleni Marques Toigo Palynology Laboratory - LPMMT / UFRGS for their support in the preparation of the palynological slides and UFAM for providing all the necessary structure and support to carry out this research. To the anonymous reviewers for their suggestions and significant contribution.

\section{ARTICLE INFORMATION}

Manuscript ID: 20180130. Received on: 11/28/2018. Approved on: 10/25/2019.

P.F.R. worked on identifying the species found on the palynological slides, wrote the first version, prepared all figures and tables and made corrections in all stages until the final version of the manuscript. R.S. participated in field collection, revised and improved the text (mainly the items Age and Conclusion), as well as provided suggestions for interpretation of palynological data. R.B. has treated and interpreted all faciological data.

Competing interests: The authors declare no competing interests.

\section{REFERENCES}

Achab A., Paris F. 2007. The Ordovician chitinozoan biodiversification and its leading factors. Palaeogeography, Palaeoclimatology, Palaeoecology, 245 (1-2):5-19. https://doi.org/10.1016/j.palaeo.2006.02.030

Almeida F.F.M., Carneiro C.D.R. 2004. Inundações marinhas fanerozóicas no Brasil e recursos minerais associados. In: Mantesso-Netto V., Bartorelli A., Carneiro C.D.R., Brito-Neves B.B. (Eds.), Geologia do continente SulAmericano: evolução da obra de Fernando Flávio Marques de Almeida. São Paulo, Beca, p. 43-58

Alvarez F., Chacón M.L.M. Braquiópodos. 2009. In: Chacón M.L.M., Rivas P. (Eds.), Paleontologia de Invertebrados. Oviedo, Ediciones de la Universidad de Oviedo, p. 377-418.

Arnott R.W.C., Southard J.B. 1990. Exploratory flow-duct experiments on combined-flow bed configurations, and some implications for interpreting storm-event stratification. Journal of Sedimentary Petrology, 60:211-219. https://doi.org/10.1306/212f9156-2b24-11d7-8648000102c1865d

Azevedo-Soares H.L.C. 2009. The Trombetas Group chitinozoans of the Amazon Basin, Northern Brazil. Neues Jahrbuch für Geologie und Paläontologie, 253(1):133-143.https://dx.doi.org/10.1127/0077-7749/2009/0253-0133

Azevedo-Soares H.L.C., Grahn Y. 2005. The Silurian - Devonian boundary in the Amazon Basin, northern Brazil.NeuesJahrbuch für Geologie und Paläontologie, 236(1/2):79-94. https://dx.doi.org/10.1127/njgpa/236/2005/79
Breuer P., Al-Hajri S., Lé Hérissé A., Paris F., Steemans P., Verniers J., Wellman C.H. 2017. A distinctive marginal marine palynological assemblage from the Pridoli of Northwestern Saudi Arabia. Revue de Micropaléontologie, 60(3):371-402. https://doi.org/10.1016/j.revmic.2017.02.002

Caputo M.V. 1984. Stratigraphy, Tectonics, Paleoclimatology and Paleogeography of Northern Basins of Brazil. PhD Thesis, University of California, Santa Barbara, 586p.

Cardoso T.R.M., Rodrigues M.A.C. 2005. Acritarcos e Prasinófitas do Siluriano da Bacia do Amazonas: um poderoso auxílio na calibração bioestratigráficas do Grupo Trombetas. Anuário do Instituto de Geociências, 28(1):131-142

Carozzi A.V., Pamplona H.R.P., Castro, J.C., Contreiras, C.J.A. 1973. Ambientes deposicionais e evolução tectono-sedimentar da seção clástica paleozoica da Bacia do Médio Amazonas. In: Congresso Brasileiro de Geologia, 27., Aracaju. Anais ..., p. 279-314.

Cheel R.J., Leckie D.A. 1993. Hummocky cross-stratification. In Wright V.P. (Ed.), Sedimentology Review. Cambridge, Blackwell Scientific Publication, p. 103-122.

Clarkson E.N.K. 2007. Invertebrate palaeontology and evolution. Edinburgh, Blackwell Science, 443 p. 
Cunha P.R.C. 2000. Análise estratigráfica dos sedimentos eo/mesodevonianos da porção ocidental da Bacia do Amazonas sob a ótica da estratigrafia de sequências no interior cratônico. Ms Dissertation, Instituto de Geociências, Universidade Federal do Rio Grande do Sul, Porto Alegre, 263p.

Cunha P.R.C., Melo J.H.G., Silva O.B. 2007. Bacia do Amazonas. Boletim de Geociências da Petrobras, 15(2):227-251.

Della Fávera J.C. 2008. Ambientes Marinhos Rasos. In: Silva A.J.C.L.P., Aragão M.A.N.F., Magalhães A.J.C. (Eds.), Ambientes de Sedimentação Siliciclástica do Brasil. São Paulo, Beca, p. 224-243.

Díaz-Martínez E., Grahn Y. 2007. Early Silurian glaciation along the western margin of Gondwana (Peru, Bolivia and Northern Argentina): Palaeogeographic and geodynamic setting. Palaeogeography, Palaeoclimatology, Palaeoecology, 245(1-2):62-81. https://doi. org/10.1016/j.palaeo.2006.02.018

Dumas S., Arnott R.W.C. 2006. Origin of hummocky and swaley crossstratification - the controlling influence of unidirectional current strength and aggradation rate. Geology, 34(12):1073-1076. https://doi. org/10.1130/G22930A.1

Fernandes A.C.S., Borghi L., Carvalho I.S., Abreu C.J. (eds.). 2002. Guia dos Icnofósseis de Invertebrados do Brasil. Rio de Janeiro, Interciência, 260 p.

Fonseca V.M.M. 2004. Braquiópodes. In: Carvalho I.S. (ed.), Paleontologia. Rio de Janeiro, Interciência, p. 651-674.

Gonçalves M.A., Soares J.L., Santos H.P., Nogueira A.C.R. 2017. Traços fósseis dos depósitos marinhos rasos da Formação Pitinga, Siluriano Superior da Bacia do Amazonas, Rio Tapajós, PA, Brasil. Revista Brasileira de Paleontologia, 20(2):179-194. http://dx.doi.org/10.4072/rbp.2017.2.03

Grahn Y. 1992. Revision of Silurian and Devonian strata of Brazil. Palynology, 16(1):35-61. https://doi.org/10.1080/01916122.1992.9989406

Grahn Y. 2005a. Devonian chitinozoan biozones of Western Gondwana. Acta Geologica Polonica, 55(3):211-227.

Grahn Y. 2005b. Silurian and Lower Devonian chitinozoan and biostratigraphy from the Trombetas Group in the Amazonas Basin, northern Brazil. Bulletin of Geosciences, 80(4):245-276.

Grahn Y. 2006. Ordovician and Silurian chitinozoan biozones of western Gondwana. Geological Magazine, 143(4):509-529. https://doi. org/10.1017/S001675680600207X

Grahn Y., Melo J.H.G. 2003. Silurian-Devonian chitinozoan biostratigraphy along the Urubu, Uatumã and Abacate rivers in the western part of the Amazonas Basin, northern Brazil. Bulletin of Geosciences, 78(4):373-391.

Grahn Y., Paris F. 1992. Age and correlation of the Trombetas Group, Amazonas Basin, Brazil. Revue de Micropaléontologie, 35(3):197-209.

Grahn Y., Paris F. 2011. Emergence, biodiversification and extinction of the chitinozoan group. Geological Magazine, 148(2):226-236. https://doi. org $/ 10.1017 /$ S001675681000052X

Holz M., Simões M.G. 2002. Elementos Fundamentais de Tafonomia. Porto Alegre, Editora da Universidade Federal do Rio Grande do Sul, 231p.

Johnson M.E. 2006. Relationship of Silurian sea-level fluctuations to oceanic episodes and events. GFF, 128(2):115-121. https://doi. org/10.1080/11035890601282115

Keighley D.G., Pickerill R.K. 1995. The ichnotaxa Palaeophycus and Planolites: Historical perspectives and recommendations. Ichnos, 3(4):301309. https://doi.org/10.1080/10420949509386400

Laufeld S. 1974. Silurian Chitinozoa from Gotland. Fossils and Strata, (5): 130 .

Matsuda N.S., Winter W.R., Wanderley-Filho J.R., Cacela A.S.M. 2010. O Paleozoico da borda sul da Bacia do Amazonas, Rio Tapajós - Estado do Pará. Boletim Geociências da Petrobras, 18(1):123-152.

Mauller P.M., Grahn Y., Cardoso T.R.M. 2009. Palynostratigraphy from the Lower Devonian of the Paraná Basin, South Brazil, and a revision of contemporary Chitinozoan biozones from Western Gondwana. Stratigraphy, 6(4):313-332.

Melo J.H.G., Loboziak S. 2003. Devonian-Early Carboniferous miospore biostratigraphy of the Amazon Basin, northern Brazil. Review of Palaeobotany and Palynology, 124:131-202. https://doi.org/10.1016/ S0034-6667(02)00184-7
Miall A.D. 2006. The geology of fluvial deposits: sedimentary facies, basin analysis, and petroleum geology. Berlin, Springer-Verlag, $582 \mathrm{p}$.

Nichols G., Williams E., Paola C. (Eds.). 2007. Sedimentary Processes, Environments and Basins: A Tribute to Peter Friend. New Jersey, Blackwell Publishing, $636 \mathrm{p}$.

Nogueira A.C.R., Truckenbrodt W., Soares E.A.A. 1999. O icnogênero Arthrophycus de depósitos sublitorâneos da Formação Nhamundá (Siluriano Inferior) da Bacia do Amazonas, região de Presidente Figueiredo. Revista Brasileira de Geociências, 29(2):135-140.

Owen G. 2003. Load structures: gravity-driven sediment mobilization in the shallow subsurface. In: Van Rensbergen P., Hillis R.R., Maltman A.J., Morley C.K. (Eds.), Subsurface sediment mobilization. Special Publication 216, London, Geological Society, p. 21-34.

Paris F. 1981. Les chitinozoaires dans le Paleozoïque du sud-ouest de l'Europe: cadre géologique, étude systématique, biostratigraphie. Memoires de la Société Géologique et Minéralogique de Bretagne, 26:1-412.

Paris F., Winchester-Seeto T., Boumendjel K., Grahn Y. 2000. Toward a global biozonation of Devonian chitinozoans. CFS Courier Forschungsinstitut Senckenberg, 220(220):39-55.

Pemberton S.G., Frey R.W. 1984. Ichnology of storm-influenced shallow marine sequence: Cardium Formation (Upper Cretaceous) at Seebe, Alberta. Canadian Society of Petroleum Geologists, Memoir, 9:281-304.

Plint A.G. 2010. Wave-and Storm-Dominated Shoreline and ShallowMarine Systems. In: James N.P., Dalrymple R.W. (Eds.), Facies Model 4. Geological Association of Canada, p. 167-200.

Potter P.E., Maynard J.B., Depetris P.J. 2005. Mud and Mudstones. BerlinHeidelberg-New York, Springer, $244 \mathrm{p}$

Reineck H.E., Singh I.B. 1980. Deposicional Sedimentary Environments. New York, Springer-Verlag, $551 \mathrm{p}$.

Schieber J. 2011. Reverse engineering mother nature: shale sedimentology from an experimental perspective: Sedimentary Geology, 238(1-2):1-22. https://doi.org/10.1016/j.sedgeo.2011.04.002

Schieber J., Southard J.B. 2009. Bedload transport of mud by floccule ripples: direct observation of ripple migration processes and their implications. Geology, 37(6):483-486. https://doi.org/10.1130/G25319A.1

Schieber J., Southard J.B., Thaisen K. 2007. Accretion of mudstone beds from migrating floccule ripples. Science, 318(5857):1760-1763. https:// doi.org/10.1126/science.1147001

Seilacher A. 2007. Trace Fossil Analysis. Berlin, Springer, 226 p.

Souza V.S., Nogueira A.C.R. 2009. Seção geológica Manaus - Presidente Figueiredo (AM), borda norte da Bacia do Amazonas: um guia para excursão de campo. Revista Brasileira de Geociências, 39(1):16-29. http:// dx.doi.org/10.25249/0375-7536.20093911629

Steemans P., Rubinstein C., Melo J.H.G. 2008. Siluro-Devonian miospore biostratigraphy of the Urubu River area, western Amazon Basin, northern Brazil. Geobios, 41(2):263-282. http://dx.doi.org/10.1016/j.geobios.2007.06.003

Teixeira L.B. 2001. Evidência geofísica de rifts precursores nas bacias paleozoicas do Amazonas, Paraná, Parecis, Parnaíba, Solimões e Alto Tapajós. In: Melo J.H.G., Terra G.J.S (Eds.), Correlações de Sequencias Paleozoicas Sul-Americanas, 20, Rio de Janeiro, Ciência Técnica Petróleo Seção Exploração de Petróleo, Petrobras, p. 1-8.

Tomassi H.Z., Almeida C.M., Ferreira B.C., Brito M.B., Barberi M., Rodrigues G.C., Teixeira S.P., Capuzzo J.P., Gama-Júnior J.M., Santos M.G.K.G. 2015. Preliminar results of paleontological salvage at Belo Monte Powerplant construction. Brazilian Journal of Biology, 75(3 Suppl. 1):277289. http://dx.doi.org/10.1590/1519-6984.1714BM

Verniers J., Nestor V., Paris F., Dufka P., Sutherland S., Grootel G.V. 1995. A global Chitinozoa biozonation for the Silurian. Geological Magazine, 132(6):651-666. https://doi.org/10.1017/S0016756800018896

Walker R.G. 1992. Facies, facies models and modern stratigraphic concepts. In: Walker R.G., James N. P. (Eds.), Facies Models - Response to sea level change. Geological Association of Canada, p. 1-14.

Wood G.D., Gabriel A.M., Lawson J.C. 1996. Palynological techniques processing and microscopy. In: Jansonius J., McGregor D.C. (Eds.), Palynology: principles and applications, 1, Dallas, American Association of Stratigraphic Palynologists Foundation, p. 29-50. 